\title{
Implications of salep collection for the conservation of the Elder-flowered orchid (Dactylorhiza sambucina) in Epirus, Greece
}

\author{
Martha Charitonidou' ${ }^{1}$, Kalliopi Stara ${ }^{1}$, Konstantinos Kougioumoutzis $^{1,2}$ and John M. Halley ${ }^{1 *}$
}

\begin{abstract}
Background: In Epirus, Greece, orchids have been traditionally harvested for the production of salep, a beverage made from their tubers. Over-collection of orchids for salep is believed to be a growing threat to wild species, yet very little research has concentrated on orchid populations in the wild. Here, we studied the impact of salep collection on population demographic parameters and uniformity of distribution patterns of the Elder-flowered orchid, Dactylorhiza sambucina, the most commonly collected orchid in northern Greece.

Methods: We carried out fieldwork in four meadows where salep harvesting occurs, and conducted interviews in villages close to these sites. Fieldwork focused on the demographic parameters of orchid populations and on the characteristics of their habitat (natural-anthropogenic). We also measured population size and distribution, extent and multi-scale density, comparing distributions to Poisson and fractal models.

Results: According to interviews, salep collection by the local community has decreased, contrary to collection by people outside the community, which is increasing. Interviewees did not believe that orchid abundance was higher in the past; they claim that it can be very variable. None of the participants seemed aware of the legislation to conserve orchids. Demographic parameters did not seem to be strongly dependent on whether it was a harvested and non-harvested sites and population density was greatest in the site of highest collection pressure.

Conclusions: Our findings show that salep collection is still ongoing in Epirus. Our interview results and our population study indicate that current levels of collection are not significantly affecting the abundance of the Elder-flowered orchid in Epirus subalpine meadows. However, the expanding commercial collection could reach levels that threaten the species. There is a need for a longer-term monitoring of these orchid populations, and a more effective modeling of the species' response to different harvesting pressures.
\end{abstract}

Keywords: Orchids, Salep, Non Timber Forest Products (NTFP), Wild products, Illegal trade, Conservation value, Northern Greece, Northern Pindos National Park

\section{Background}

The Orchidaceae, one of the oldest vascular plant families (76-112 My old) [1-3], have an almost global distribution, yet they are absent from the deserts and the poles

${ }^{*}$ Correspondence: jhalley@cc.uoi.gr

${ }^{1}$ Laboratory of Ecology, Department of Biological Applications \& Technology, University of loannina, 45110 loannina, Greece

Full list of author information is available at the end of the article
$[4,5]$. They are also the most diverse vascular plant family comprising ca. 736 genera and ca. 28,000 species $[6$, 7]. Since their first mention in Chinese medical texts around $2800 \mathrm{BC}$ [8], orchids have always been in the spotlight of plant enthusiasts and scientists. The allure of their beauty, their striking appearance and their "endless diversity of structure" [9] has excited a curiosity that

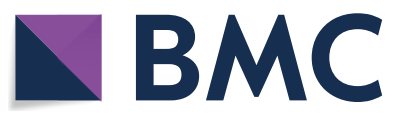

(c) The Author(s) 2019. This article is licensed under a Creative Commons Attribution 4.0 International License, which permits use, sharing, adaptation, distribution and reproduction in any medium or format, as long as you give appropriate credit to the original author(s) and the source, provide a link to the Creative Commons licence, and indicate if changes were made. The images or other third party material in this article are included in the article's Creative Commons licence, unless indicated otherwise in a credit line to the material. If material is not included in the article's Creative Commons licence and your intended use is not permitted by statutory regulation or exceeds the permitted use, you will need to obtain permission directly from the copyright holder. To view a copy of this licence, visit http://creativeco mmons.org/licenses/by/4.0/. The Creative Commons Public Domain Dedication waiver (http://creativecommons.org/publicdomain/ zero/1.0/) applies to the data made available in this article, unless otherwise stated in a credit line to the data. 
has sometimes been detrimental to orchid conservation. From at least the nineteenth century, orchids have been over-collected for scientific, ornamental and medicinal purposes [10-13], which has arguably brought many species to the edge of extinction [14]. Regarding this, several orchid species have been assessed by IUCN, with the threat status for the ones that are directly threatened varying from Vulnerable to Critically Endangered [15]. In terms of legislative actions, many orchid species are included in local (the Greek Presidential Decree 67/1981), regional (Annexes A and B of the Council Directive 92/43/EEC in the European Union) and global (Appendices I and II of the Convention on International Trade of Endangered Species of Fauna and Flora-CITES) protection/conservation laws, that prohibit their collection and harvest, as well as any commercial use [16].

Since ancient times [as mentioned in works by Theophrastus (ca. 300 B.C.), and later on, Dioscorides (ca. 60 A.D.)], orchids have been collected in the Eastern Mediterranean for their putative healing properties. Orchid harvesting continued during the Ottoman Rule (mid fifteenth to early twentieth century), while recently, the pace of orchid harvesting has been increasing again [17], because of the uprising market demand for salep (Greek: salepi), a flour made from dried orchid tubers $[18,19]$. The etymology of the word sālep derives from Arabic (kusa-' $t$-) $t a l l a b$, the name for an orchid that literally means 'fox's testicles' [20]. Salep is popular primarily in Turkey, but also in Greece, Iran, Iraq and Albania [21, 22 ]. It is mainly sold by street vendors during winter, as a remedial hot beverage for cold and cough in the aforementioned countries [23]. It has also a long tradition in gourmand and culinary products as key ingredient in the famous dondurma (Kahramanmaras) ice cream in Turkey [24] and kaimaki ice cream in Greece [17]. However, salep overharvesting is a serious threat increasing the extinction risk of orchid species in the region $[25,26]$. Orchids that are collected for salep, belong to genera that bear ovoid bulbs or palmate tubers. In general, salep is made from at least 35 different species of orchids [27], with Anacamptis, Orchis and Dactylorhiza species being the most common "salep orchids" [18].

Greece is highly diverse in orchids, with Epirus (northwest Greece) being among the most species-rich areas, hosting ca. 70 taxa $[28,29]$. The most commonly harvested species for salep in Greece are Anacamptis morio, Dactylorhiza sambucina, D. saccifera and Orchis mascula $[26,30]$. Other orchids, mainly from the genera Anacamptis and Orchis are also mentioned from older references [31-33]. A large fraction of the salep collected in Greece and neighbouring countries, finds its way to the international market mainly through the Netherlands, Northern Cyprus [34], and especially Germany, which is by far the largest trader in medicinal and aromatic plants [35]. The current high demand has also resulted in the increasing use of substitutes, such as rice powder and carboxymethyl-cellulose (CMC) to meet the market needs [34]. However, there has been a revived demand for authentic salep, along with other forest food plants and "Non-Timber Forest Products" (NTFP) in general, as part of modern people's desire to be reconnected with Nature, with traditional culture and with their own locality [36]. Ironically, this yearning for reconnection with Nature may actually drive local extirpation for many vulnerable species, including orchids $[16,22,37]$ because of its potential magnitude. For example, in Europe, the official value of the market in plant and mushroom products alone was estimated at $€ 1.68$ billion [38]. The unregulated and undocumented orchid harvest and trade relating to salep is expected to be very large and to put pressure on populations in the wild. To that end, research into trade dynamics and the impacts of harvest are very important.

Although several relevant studies have been carried out dealing with the ecology, genetic diversity and conservation of these orchids [39-42], less work has been done on orchids specifically collected for salep [26, 37]. Existing studies outline the threat to orchid populations, but there has been very little examination of populations themselves. Since population is such an important concept in conservation, we need an integrated approach that will examine the impact of salep collection on orchid populations [43]. Thus, our aim is to investigate the impact of salep harvesting on population demographic parameters and distribution patterns of Dactylorhiza sambucina in Epirus, interviewing local collectors and considering the background cultural history of orchid harvesting.

\section{Results \\ Results from interviews}

Salep collection is not an easy task; there are only a few people in every village we visited, who know the plants and have inherited the practice as a family tradition. From the six commercial collectors we interviewed, five still collect salep, as a supplementary occupation and the quantities mentioned are 10-100 kgr of dry tubers per collector or collectors (e.g. husband and wife) per season. Collection is also an attractive activity for economic migrants who work in Greece as shepherds and supplement their low salaries by collecting from the wild plants of economic interest including salep. Prices depend on networking, negotiation and the collector's position in the product value chain and they can vary from 10 to 80 euros per kilo of dry tubers, while ground salep price in the market rises at 120-180 euros per kilo. These people collect mainly Dactylorhiza sambucina, though they are also familiar with other orchid species, based on the 
results of our interviews. They distinguish the species by the different shape of its tubers (oval or palmate) and by the habitat they find it (forest edges, wet places, summer pastures). They collect all species mainly from early June to mid-July, when they are in flower and it is easier to spot them among the vegetation. Later in the summer, even if the product's quality is much better, it is more difficult to spot the orchids due to the surrounding vegetation or because the sheep graze the upper part of the plant.

Collectors uproot the plants with a shovel specially designed for salep, selecting the new tubers for collection. After collection, they wash and dry the tubers, using a needle and a thread, sewing them together and then hanging the string of tubers for drying if the quantity is small or they use large fabrics to dry the tubers in the sun for bigger quantities. Most of our informants claim to be unaware of the protection status of orchids and they think that the same rules are applied as for other medicinal plants. Nevertheless, the presence and controls of the local Police or Forestry Service in harvest areas, not only for orchids but also for other species of commercial interest (e.g. Sideritis raeseri, Primula veris) during summer 2018 is mentioned as a discouraging factor for commercial collectors. None said that they had observed a systematic decrease in natural populations, only large variability from year to year, which they attribute to variable winter and spring weather conditions, especially precipitation. Our informants consider wild boar disturbance of the habitat and bad collection practices, i.e. discarding the stems with the last-year tubers and not covering the dug after uprooting the plants, as the main threat to the species. On the contrary, good collection practices, i.e. replanting the remaining tuber and stem, are believed to help the plants spread their seeds, survive and flower again the following year.

\section{Demographic parameters and population profiles}

All the demographic parameters observed in situ and calculated from field measurements are presented in Table 1 . All sampling sites are characterized by presence of one- or two-leaf juveniles, although in the Anthochori site, due to the presence of dense grass, it was very difficult to spot them. The average number of flowers per shoot (FLN) varied among sites, with the highest observed in Lakmos and the lowest in Anilio (13.5 and 10.3, respectively). The number of fruits per shoot (FRN) on the other hand, was lowest in Lakmos and highest in Anilio (3.8 and 6.0, respectively). The percentage of pollination success differs among the sampling sites, ranging from $13.5 \%$ in Lakmos, up to $53.5 \%$ in Anthochori. Using the mean capsular seed number for D. sambucina, as proposed by Sonkoly et al. (as described in "Methods"), we found that in Anilio, the seed number per shoot (SNS) was larger than in all other populations $(\mathrm{SNS}=18,084)$. Harvest status did not have any statistically significant influence on any of the demographic parameters we measured ( $p>0.05$ in all cases).

\section{Disturbances and human presence on sites}

All studied populations were impacted by human presence: in three out of four sites (except Anthochori), road proximity is high, and the populations are easily accessible. Human presence and activities were regular, with grazing (mainly sheep but also goats and cows) being the most common disturbance, except in Anthochori, which is turning from a regular and highly grazed area to an almost abandoned pasture, since only one shepherd uses the place for his herd. Tymfi was severely grazed, with numerous inflorescences missing from individuals, while extensive amounts of animal waste as well as human signs (discarded cigarettes and other mainly plastic litter) were also observed. In all sites Helleborus odorus subsp. cyclophyllus was present, a plant species that is linked to heavy grazing. Almost all sites hosted other plant species of collection interest, like mountain tea (Sideritis raeseri subsp. raeseri), common primrose (Primula veris) or the great yellow gentian (Gentiana lutea), that are all known to be excessively collected for medicinal use. In some populations like Tymfi and Lakmos we observed signs of precollection marking on D. sambucina individuals; at the first, we found plants that were excavated and then put

Table 1 Demographic parameters of the studied populations

\begin{tabular}{lclllcllll}
\hline Site code & N & JPR & IND & FLM & FRM & PS (\%) & FLN & FRN & SNS \\
\hline ANIL & 119 & Yes & 30 & 310 & 72 & 23.2 & 10.3 & 6.0 & 18,084 \\
ANTH & 188 & $-\mathrm{b}$ & 50 & 634 & 215 & 33.9 & 12.7 & 4.3 & 12,960 \\
TYMF & 82 & No & 15 & 157 & 84 & 53.5 & 10.5 & 5.6 & 16,792 \\
LAKM & $151^{\mathrm{a}}$ & Yes & 50 & 676 & 189 & 28.0 & 13.5 & 3.8 & 11,393 \\
\hline
\end{tabular}

$N$ population size, JPR presence of juveniles, IND number of individuals measured, FLM total number of counted flowers, FRM total number of counted fruits, PS (\%) percentage of pollination success, FLN average number of flowers per stem, FLN average number of fruits per stem, SNS average seed number per shoot

a This population size for LAKM represents a cluster of a bigger population; the total size is estimated based on the area and field observations

b " $-"=$ the presence of juveniles in ANTH could not be measured due to dense grass 
back in place, while at the latter, we found plants excavated with their bulbs missing, as well as plants that were marked by leaving a circle of bare ground around them. Moreover, at two sites (Anilio-Lakmos), we observed big holes on the ground, footprints, as well as excavated and thrown plants with their tubers, evidence that point to the presence of wild boars in the area.

\section{Measuring populations and distribution Individuals counted}

The number of flowering individuals was counted in all four sites, Anthochori, Anilio, Tymfi and Lakmos respectively (Table 1). In the first three cases these were full local flowering populations, while the sample for Lakmos was part of a larger local population. Also, in Tymfi, only 15 out of the 82 total individuals actually carried flowers due to the heavy grazing in the area.

\section{Scale-dependent density}

The density measured in the four populations is different, ranging from 6.8 plants per hectare in the Anilio population to 218.8 in the Lakmos population. This is equivalent to a mean walking distance between nearest plants of $6.8 \mathrm{~m}$ in Lakmos to $38.4 \mathrm{~m}$ in Anilio. From Table 2, we see there is a high occupancy at larger scales for Anilio, with $43 \%$ occupancy at level-0; this means that in most replicate simulations, 7 out of 16 of the $128 \mathrm{~m}$ subsquares are occupied.

Although they do not entirely fit either a Poisson model (spatially-uniform) or fractal model (scale-free), the occupancy patterns in Fig. 1 are closer to fractal than to a Poisson distribution. Specifically, according to the $p$-values in Table 2 , only in the case of Anilio does a regression test yield a significant indication of occupancy increasing with scale as might be expected with a Poisson. The fractal model dimensions fitted to the observed populations were all in the order of 1.26 to 1.38 , which is a rather narrow band of values that may be fortuitous. The number of points we use is too small to provide strong evidence for a fractal model. It is however significant that there is evidence for a constant occupancy as a function of scale. The number of individuals in the Lakmos population is larger than 151 counted, as ours was only a sample within a small area. Under normal sampling assumptions (Poisson model), we assume that population scales with area (i.e. is proportional to $L^{2}$ ). However, since the fractal model seems to be more consistent with our observations, the scaling regime is more likely to be fractional (i.e. in this case proportional to $L^{1.3}$ ).

Table 3 summarizes some of the results of the population distribution survey. The area of the orchid meadows at Lakmos was calculated using QGIS version 3.6.0 'Noosa' [44]. We observed the limits of the population in various directions in order to obtain a polygon containing the local population. We then found the area of the square enclosing this polygon. We calculated $L$ as the square root of this area, then used Eqs. (2) and (3) to estimate the dimension and the total population, respectively. The salep yield was found using data from Sezik [18] that one kilogram of salep requires 2620 bulbs. Of the four populations, only Lakmos has a large number of plants and is capable of producing salep in substantive quantities.

\section{Discussion}

The Elder-flowered orchid, Dactylorhiza sambucina (L.) Soó, is one of the most important orchids collected for salep in Epirus. According to IUCN's Red List Species assessment, the Elder-flowered orchid, although locally abundant across its range, it is considered to be in decline. This is argued on the basis of various threats, mostly linked with habitat change and human disturbances [45]. The species is also among those considered

Table 2 The density measured as the level of occupancy in the four populations we studied and the corresponding parameters for the fractal and Poisson models

\begin{tabular}{|c|c|c|c|c|c|c|c|c|}
\hline Level & $\begin{array}{l}\text { Width of cell } \\
\text { (m) }\end{array}$ & $\begin{array}{l}\text { Sub-cell width } \\
(\mathrm{m})\end{array}$ & Total cells & Sampled/repl. & ANTH & ANIL & TYMF & LAKM \\
\hline 0 & 512 & 128 & 1 & 1 & $14 \%$ & $43 \%$ & $19 \%$ & $14 \%$ \\
\hline 1 & 128 & 32 & 16 & 2 & $18 \%$ & $20 \%$ & $26 \%$ & $13 \%$ \\
\hline 2 & 32 & 8 & 256 & 4 & $26 \%$ & $13 \%$ & $13 \%$ & $23 \%$ \\
\hline 3 & 8 & 2 & 4096 & 8 & $12 \%$ & $7 \%$ & $8 \%$ & $16 \%$ \\
\hline 4 & 2 & 0.5 & 65,536 & 16 & $23 \%$ & $7 \%$ & $7 \%$ & $9 \%$ \\
\hline \multicolumn{5}{|c|}{$r$, Poisson rate $/ \mathrm{m}^{2}$} & 0.00072 & 0.00045 & 0.00031 & 0.00058 \\
\hline \multicolumn{5}{|l|}{$A \vee \cdot p_{F}$} & 0.19 & 0.18 & 0.15 & 0.15 \\
\hline \multicolumn{5}{|l|}{$p$ value } & 0.590 & 0.038 & 0.077 & 0.750 \\
\hline
\end{tabular}

Also shown are the results of testing for an increase of occupancy with scale, that would indicate a Poisson pattern (uniformly spread throughout the landscape) by means of $p$-values 

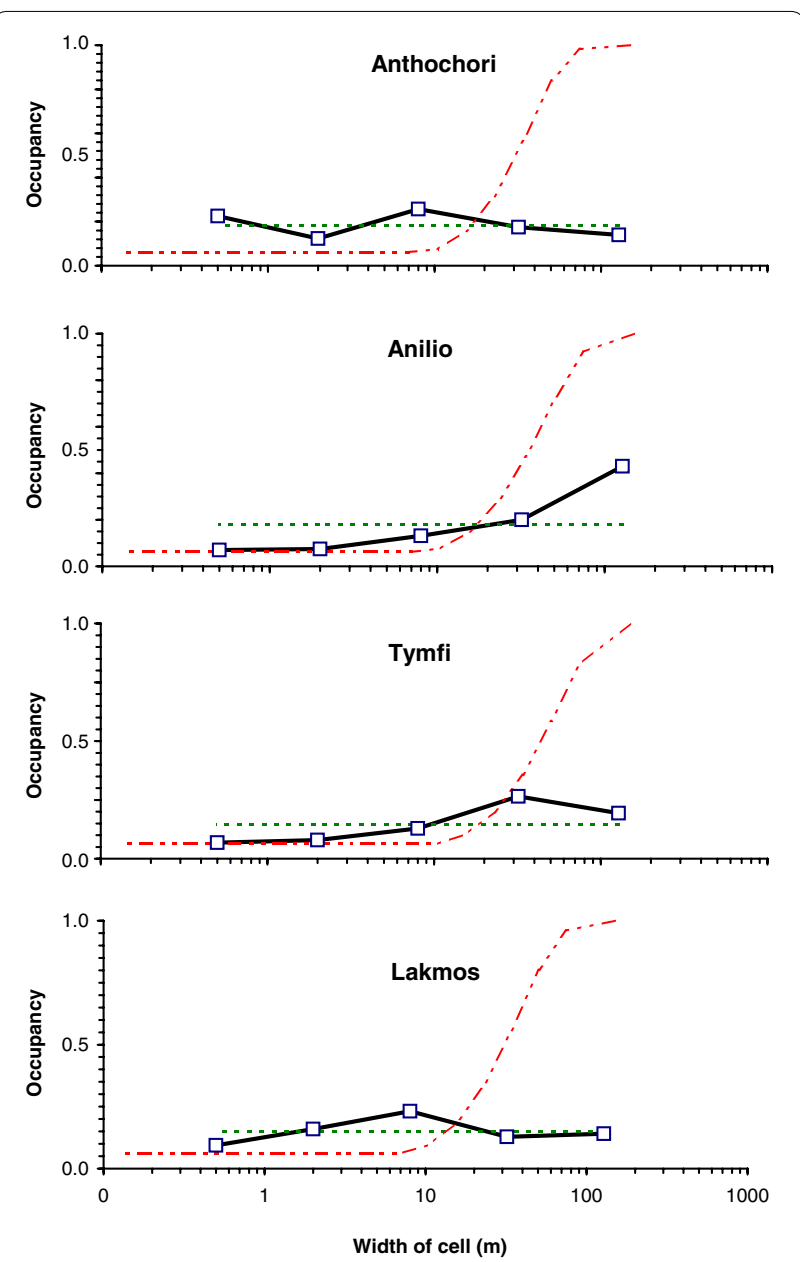

Fig. 1 Patterns of population density as a function of cell size. Occupancy is the average proportion of sub-cells occupied when a cell is subdivided into 16 smaller units. In each case the width refers to the sub-cell size, not the mother-cell size. For each population the solid curve is the outcome of 1000 simulations obtained by locating the grid in slightly different positions relative to the population. The black line is the average. The thin broken line is the occupancy of the equivalent fractal model while the rising broken curve is the occupancy of the equivalent Poisson distribution

Table 3 Population distribution features observed by us and their implications for salep production

\begin{tabular}{lclcl}
\hline Site code & Extent, $L^{\mathbf{2}}$ (ha) & $\begin{array}{l}\text { Dimension } \\
\boldsymbol{D} \text { (est.) }\end{array}$ & $\begin{array}{l}\text { Population } \\
\boldsymbol{N} \text { (est.) }\end{array}$ & $\begin{array}{l}\text { Potential } \\
\text { salep yield } \\
\text { (kg) }\end{array}$ \\
\hline ANTH & 1.76 & 1.38 & 188 & 0.072 \\
ANIL & 17.58 & 1.30 & 119 & 0.045 \\
TYMF & 1.79 & 1.26 & 82 & 0.031 \\
LAKM & 1849.00 & 1.30 & 25,751 & 9.829
\end{tabular}

The estimate of the extent of Lakmos site was approximate, obtained by finding the extremes of the local population. The fractal dimension, $D$, was calculated using Eq. (2) and the population, $N$, using Eq. (3) by Kreziou et al. [26], who note that orchid abundance has decreased in contrast to the past, and the present populations are likely to be severely affected by overcollection. So is this orchid threatened by current and anticipated levels of collection for salep? Like all orchids that grow in subalpine meadows, $D$. sambucina is subject to various threats and variability associated with its interactions with human presence, since this habitat is also used as pasture for livestock. Indeed, we observed grazing signs in all our study sites: absence of woody shrubs, low grass, species that are grazing indicators (e.g. Helleborus odorus subsp. cyclophyllus), and in some cases like Tymf, we found numerous Dactylorhiza sambucina individuals with bitten stems. This is also noted in interviews; people who used to collect this species as salep, preferred to collect when the species was in flower, since it was easier to spot it, as later in summer the plants were eaten by grazing animals. When at high intensity and frequency, grazing can be an important factor that may increase the mortality, and thus, limit the overall reproductive capacity of populations in the meadows where the Elder-flowered orchids grow [46-48]. However, in Epirus, subalpine meadows have traditionally been used by transhumant shepherds as summer pastures $[49,50]$; such grazing, which occurs during the reproduction period of the plant, seems to have had only small impact on the long-term viability of populations. However, when such pastures are left abandoned, then woody vegetation overgrows and affects orchid abundance [51], especially of species like D. sambucina, which need open spaces and grasslands to grow [52]. Indeed, intermediate levels of grazing can benefit orchids because it forestalls reforestation. Fischer and Wipf [53] found that in sites where grazing occurs, the percentage of shrubs and woody plants was low, while Köhler et al. [54] found that orchids can be benefited from moderate grazing, since it maintains low species competition, favourable conditions (space and lighting), as well as will enhance useful soil nutrients. The Mediterranean landscape is undoubtedly shaped by human presence [55], and its flora is replete with many examples of the co-evolution of plants with grazing animals $[56,57]$. In comparison to the past, these meadows are now undergrazed [58]. It should be noted that, in Epirus, there is a current trend to introduce more cattle in subalpine pastures (personal observations), which replace sheep that traditionally graze summer pastures, causing the disturbance regime to shift from grazing to trampling. In local culture agreements and shepherds' contracts, flock movements from lowlands to highlands (and vice versa) are marked by the holy days of the Orthodox military Saints, George (April 23rd) and Demetrius (October 26th) [59]. In addition to the concerns about reforestation or overgrazing, various other anthropogenic 
threats (e.g. wind farms and other human constructions), may negatively affect the habitat of $D$. sambucina in the future. However, at present we consider that this species is most likely to be impacted by collection for salep; a procedure accelerated by the rapid growth of the market for salep in recent years. It must be noted that, harvesting orchids for salep involves the removal of the tubers, which actually kills the plants, in contrast to grazing, that only removes the above ground parts (i.e. the reproductive tissues).

Despite protection of all Orchidaceae under European and Greek law, our study shows that orchids continue to be collected for salep in Epirus, and most respondents declared themselves unaware of the protection status of orchids. The growing popularity of salep can only be expected to increase pressure on populations in Epirus in the near future. The collectors in our study report a harvest of $10-100 \mathrm{~kg}$ per season. This can hardly be the lion's share of imports into Turkey, as detailed by Sezik [18] (15-20 tonnes) and by recent reports of 80 tonnes mentioned by Hinsley et al. [60], neither of such export levels as described by Kasparek and Grimm [34]. Although the collection by locals in the areas we visited does not approach the pressures found elsewhere, our informants report increasing collection of salep by seasonal commercial collectors outside the local community. The most important question is to what extent traditional and modern harvesting pressures affect population sizes and their distributions. According to Kreziou et al. [26] "The annual harvests of thousands of $50 \mathrm{~kg}$ units of salep reported in the 1850 s... no longer occur, as orchids have become rare and remaining populations have lost resilience to such harvesting pressure". Ultimately, estimates of population resilience need to be associated with responses to measurable pressures. Thus, a survey of population performance under a harvesting regime is needed. Our basic survey is an important step towards a more integrated perspective for salep orchids. In fact, our study could not find empirical support for statistically significant differences between harvested and nonharvested study sites in any demographic or population parameter. At our four sites, distributions of populations are quite similar, exhibiting similar multi-scale patterns of occupancy. When we compare a model for a uniform distribution (Poisson) with a fractal model only one site shows a pattern of occupancy significantly more similar to uniformity. For example, neither Lakmos, the most harvested, nor Anthochori the non-harvested population, were different. Of course, the small size and span of our data (four sites of size $\sim 1$ ha for 1 year) limits the scope of conclusions we can draw from these results, and so they should be regarded as informative rather than conclusive. The low numbers of orchids in three of the sites (insignificant for salep collection) and high number in Lakmos are consistent with large spatio-temporal variability, as reported by our informants, and this could be calibrated better in a long-term study. Thus, our study underlines the need for longer-term observations of the response of orchid populations to harvesting. Some of the areas we observed have been heavily harvested for generations. So, why are there still signs of abundance in these areas, such as continuing collection for salep that requires many plants to be removed? Should salep orchids be rarer or more common? Salep is reported as collected for generations in a locally-based traditional way and it is common to be sold in herbal markets [21], but on occasion it has been fashionable across Europe [8]. The collection history of salep in Epirus is not stable, but has major fluctuations, depending on market demand. For example, salep was a very popular beverage in the eighteenth century [31] but more recently, in the 1960s, it was in high-demand from pastry shops in Athens, where it was used for the production of the traditional Greek ice-cream "kaimaki" as mentioned in our interviews with older collectors. There followed a reduction that affected mainly the street salep vendors and recently salep is in the spotlight again, due to the revival of natural products worldwide and also in Europe [36]. The consumption behaviour is strongly influenced by geographical location and neighboring countries. Not only tradition but external input such as trade and cultural exchange are strong factors shaping consumption behaviour (like in mushrooms) [61]. Perhaps our sense of abundance in Site- 4 is an illusion caused by the "shifting baseline" [62]. Populations a few 100 years ago could have been much larger. Such information might be obtainable through longerterm historical and archive studies on the production and consumption of salep in Epirus. We are thus drawn to the question of what level of harvesting is likely to cause local extinction. The sustainability of harvest is related to the reproduction strategies of specific plants, and in the harvesting practices associated with them. For example, management of medicinal plants can be improved by taking harvesting patterns, plant life forms and growth patterns into consideration [63]. However, our results do not show strong sensitivity to harvesting pressures in population demographic parameters and distributions. So, there may not be a simple connection between harvest intensity and extinction risk in these types of organisms. Orchids are characterized by very high fecundities and high seed mortality, leading to very high population variability [64] and have a life cycle that is characterized by periods of dormancy or vegetative states, so our observations may be missing important sections of the populations. Concepts like maximum sustainable yield may be harder to identify for these kinds of organisms than for 
mammals or birds. Counterintuitive patterns of insensitivity to harvest levels that have been widely observed for mushrooms [65] or sea-turtles [66], may be linked to this high-fecundity life-strategy [64]. Elsewhere it has been argued that range size is one of the best predictors of risk of local extinction from habitat loss $[67,68]$, so that range rather than collection pressure determine its resistance to anthropogenic pressures such as collection. Overall, it remains an important challenge to establish conservation boundaries for these orchid populations.

Positive developments include rapid developments in artificial germination and cultivation of orchids [69-71] and in situ and ex situ conservation efforts [72]. For this kind of species, that are highly demanded in the current market, proper management of their wild populations, ex situ conservation, as well as clonal propagation methods should be highly prioritized in the conservation agenda. Of course, there are still worries that a taste for "real" salep might activate an "anthropogenic Allee Effect". That is that people place disproportionate value on rare species [73], valuing the wild-harvested article over the cultivated one and generate a cycle of increased exploitation and rarity ultimately leading to its extinction in the wild [74].

\section{Conclusions}

Our results show that traditional style salep collection continues in Epirus, and that modern commercial collection for a growing mass-market may already be underway. This added collection is expected to put orchid populations under increased pressure. However, at present, local collectors do not report problems of abundance. In addition, our own pilot study of the demographics and distribution of $D$. sambucina populations in the area did not find strong indications of differences between harvested and non-harvested sites for any parameter. This study underlines the need for wider and longer-term observations of wild orchid populations. Also needed is a better model of how wild orchid populations respond to harvesting at different intensities.

\section{Methods}

\section{Site selection}

The northern part of Pindos Mountain Range, a region with high geomorphological heterogeneity (e.g., limestone rocks, screes, ultramafic outcrops) constitutes our wider study area. It also has a wide variety of habitats (e.g., Bosnian and black pine, fir, beech and oak forests, grasslands with Nardus stricta, oro-mediterranean heathlands and ravine forests) [28]. It hosts ca. $30 \%$ of the total orchid species present in Greece [75, 76], and is especially rich in dactylorchids (e.g. Dactylorhiza sambucina) [28, 29], some of the main salep orchids in Greece. Northern Pindos has also been identified as a place under, or soon to be under, higher collection pressure for salep [26, 77]. For our study we selected four (4) sampling sites: Anilio (ANIL), Anthochori (ANTHO), Tymfi (TYMF) and Lakmos (LAKM). Anilio, Anthochori and Tymfi were identified as frequent collection areas according to local collectors, while Anthochori site, although mentioned as a salep meadow during the interviews, none of the participants indicated the specific place as a harvesting site. According to this, the selected sites were divided into two separate categories, depending on their harvest status (collected/not collected) (Table 4). All sampling sites belong to the Pindos geotectonic zone and more specifically, three of them occur on limestones (Anilio, Anthochori and Lakmos) and one on flysch (Tymfi) [78]. The sites do not differ much in terms of $\mathrm{pH}(6.0-6.2)$ or altitude. The slope varies a little bit more (12-27\%).

\section{Study species}

We selected Dactylorhiza sambucina (L.) Soó (1962) as our study species, which is commonly known as the Elderflowered orchid and constitutes a European species, with a distribution ranging from Scandinavia down to Sicily, and from central Spain to Crimea in the East. At its southern borders it can be found in mountainous areas, in a variety of habitats including sub-alpine and alpine meadows, forest edges, open grasslands and woodlands. It usually occurs in fully sunlit places, on alkaline to slightly acidic damp soil, at altitudes of up to $2600 \mathrm{~m}$ a.s.l. [79]. In Greece, it is relatively common in the country's north and central mountainous areas (mainly across the Pindos range), where it can form large colonies, mostly in sub-alpine meadows. A distinctive feature of this orchid is its flowers' colour, ranging from whitish-yellow to light or dark violet (Fig. 2). An intermediate form with pink flowers is also sometimes observed (var. zimmermanii) [80]. Dactylorhiza sambucina is a food-deceptive orchid, pollinated mainly by bumblebees, with a flowering period between (late April-) May and July, depending on altitude [52, 80]. According to IUCN, the current extinction risk of $D$. sambucina is low (a "Least Concern" taxon), but the species' population trend is thought to be decreasing, mainly due to habitat loss and other anthropogenic threats [45].

\section{Interviews}

In order to investigate the relation of local inhabitants of Epirus with orchids, we carried out interviews with key informants and other stakeholders in villages near the areas for which we had prior indication for collection ([77], and personal observations prior to 2018). We use the term "key informants" to define people with knowledge that is more extensive, detailed or privileged than ordinary people, and thus, particularly relevant for 
Table 4 Description of sampling sites

\begin{tabular}{|c|c|c|c|c|c|c|}
\hline Site & Code & Habitat type & Harvest status & $\begin{array}{l}\text { Altitude (m) } \\
\text { and slope }\end{array}$ & Co-occurring orchid species & $\begin{array}{l}\text { Other species } \\
\text { of collection } \\
\text { interest }\end{array}$ \\
\hline Anilio & ANIL & $\begin{array}{l}\text { Grassland_-Beech for- } \\
\text { est opening }\end{array}$ & Collected & $\begin{array}{l}1460 \\
26 \%\end{array}$ & $\begin{array}{l}\text { Orchis mascula } \\
\text { Neotinea ustulata } \\
\text { Anacamptis morio }\end{array}$ & $\begin{array}{l}\text { Satureja montana } \\
\text { Primula veris }\end{array}$ \\
\hline Anthochori & ANTHO & Subalpine meadow & Not collected & $\begin{array}{l}1541 \\
27 \%\end{array}$ & - & $\begin{array}{l}\text { Gentiana lutea } \\
\text { Primula veris } \\
\text { Sideritis raeseri }\end{array}$ \\
\hline Tymfi & TYMF & Subalpine meadow & Collected & $\begin{array}{l}1553 \\
12 \%\end{array}$ & $\begin{array}{l}\text { Platanthera chlorantha } \\
\text { Neotinea ustulata } \\
\text { Anacamptis morio }\end{array}$ & $\begin{array}{l}\text { Thymus sp. } \\
\text { Acinos sp. } \\
\text { Hypericum sp. }\end{array}$ \\
\hline Lakmos & LAKM & Subalpine meadow & Collected & $\begin{array}{l}1630 \\
16 \%\end{array}$ & $\begin{array}{l}\text { Orchis mascula } \\
\text { Neottia ovata }\end{array}$ & $\begin{array}{l}\text { Gentiana lutea } \\
\text { Primula veris }\end{array}$ \\
\hline
\end{tabular}

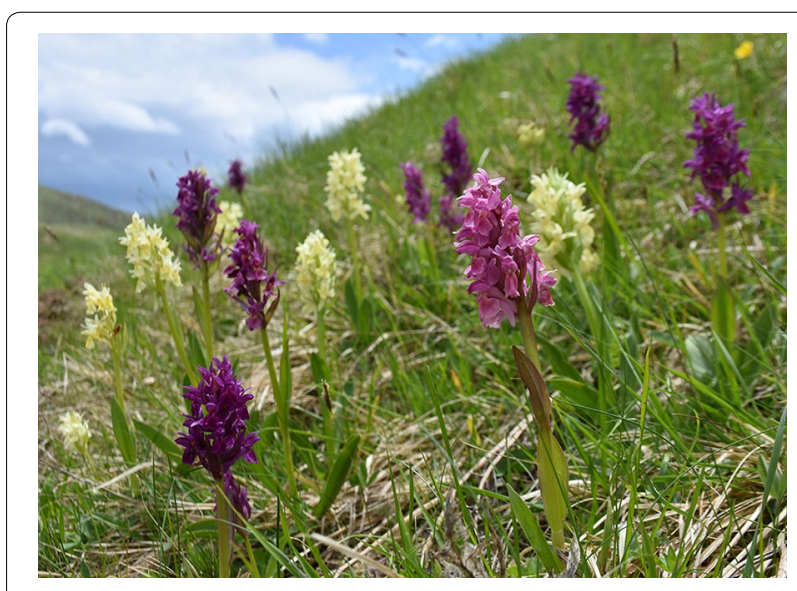

Fig. 2 The Elder-flowered orchid, Dactylorhiza sambucina (L.) Soó (1962), showing its characteristic color variation (photo credits: Kalliopi Stara)

this research [81]. In this research, key informants were expected to be collectors for private or commercial use. We approached informants using the snowball sampling method, where research participants suggest other familiars (friends, relatives, neighbors etc.) to participate in the study [82]. Interviews were carried out in five (5) villages that are the nearest to the selected sites (Anthochori, Krania, Milia, Anilio, Vradeto) and in Ioannina town. They began with a photo exercise based on colour photographs of the species Dactylorhiza sambucina, Orchis mascula and Ophrys helenae (not characterized as a salep orchid, but is found in the area). We asked participants to name the species and comment on abundance, characteristics that differentiate species and local names. We also asked about the use of orchids for salep (reasons of use, preparation of the beverage), the collection (areas and time of collection, how many years they collect, by whom they learned the practice, special tools, quantities). Other questions were about abundance, prices, qualities, market demands and processing after collection. There were also questions concerning nature conservation: past/present differences in the biotope, species abundance and perceived trends in natural populations, threats, conservation status of the species, protection measurements, practices that could ensures species survival and sustainable management. Interviews with local informants $(60$ in different villages across Pindos) took place between May 2018 and September 2019. There are also additional interviews conducted by team members prior to the project [77]. Herein, we analyze results from 15 interviews directly related with the areas where we implemented measurements in the field. We conducted the interviews in private houses (2), cafes or tavernas (6), in the field (5) and in shops that sell salep (2). Each interview lasted from 10 to 90 min and in one case it was followed by a joint visit with two local informants and three researchers to the field. In all, we interviewed 15 informants (11 men and 4 women), aged $40-74$ years (10 people) or younger than 40 (5 people) (Table 5). Six of them were characterized as key informants. Information was documented by written notes and was supplemented by video or voice recording, with the permission of the informants.

\section{Orchid fecundity, recruitment, and population profiles}

For our field study, we created a protocol divided in two sections, in order to apply to all of our sampling sites. The first section of the protocol included all the parameters that describe each sampling site. Natural characteristics of the site (e.g. altitude, slope, habitat type, co-occurring orchid species), land-use information and indications of harvesting (e.g. distance from road or other infrastructure or settlements, grazing, markings, signals, species 
Table 5 Results from interviews conducted at the nearest villages to the selected sampling sites

\begin{tabular}{|c|c|c|c|c|c|c|c|c|}
\hline \multirow[t]{2}{*}{ Site } & \multicolumn{4}{|c|}{ Informants } & \multicolumn{4}{|c|}{ Uses of $D$. sambucina } \\
\hline & Age & Men & Women & Total & Commercial & Private & None & Unknown \\
\hline \multirow[t]{2}{*}{ TYMF } & $<40$ & 1 & & 1 & 1 & & & \\
\hline & $40-74$ & 3 & & 3 & 2 & & 1 & \\
\hline \multirow[t]{2}{*}{ ANTH } & $<40$ & 1 & 1 & 2 & & & & 2 \\
\hline & $40-74$ & 2 & 1 & 3 & & & & 3 \\
\hline \multirow[t]{2}{*}{ ANIL } & $<40$ & 2 & & 2 & 2 & & & \\
\hline & $40-74$ & 1 & 1 & 2 & & & 2 & \\
\hline \multirow[t]{2}{*}{ LAKM } & $<40$ & & & & & & & \\
\hline & $40-74$ & 1 & $1^{*}$ & 2 & $1^{*}$ & 1 & & \\
\hline Totals & & 11 & 4 & 15 & 6 & 1 & 3 & 5 \\
\hline
\end{tabular}

Each line represents answers by one demographic category and how they use $D$. sambucina. The asterisk $\left(^{*}\right)$ refers to a woman who collected commercially in the past, but not currently. Note that "None" in column 8 means that the informants could identify the species but they do not collect it

of collection interest etc.), as well as observations in situ (e.g. remaining plant part, holes etc.) were included (modified field protocol of Molnár et al. [83]). The second section of the protocol focused on demographic parameters. In this section, we included parameters dealing with the above-ground part of the species' life cycle, which are directly linked to fecundity and recruitment, and can possibly be affected by salep harvesting. Thus, in each sampling site, we counted the number of flowering individuals $(N)$, and we marked the presence or absence of seedlings (juveniles-JPR). According to the population size, the flowering stage, and the overall demographic status of each population, we selected 30 to 50 individuals, and counted the total number of flowers (FLM) and fruits per stem (FRM) in each individual. The only exception was the Tymfi population, where only 15 out of the 82 total individuals were deemed suitable for measurements (fully developed inflorescence), due to severe grazing in the area. From our field measurements, we estimated the average number of fruits and flowers per shoot (FLN and FRN respectively) for non-grazed plants, as well as the percentage of pollination success (PS\%), defined as the ratio of number of fruits divided by the number of flowers. Using the mean capsular seed number for Dactylorhiza sambucina proposed by Sonkoly et al. [84], we calculated the seed number per shoot (SNS). Finally, we tested whether there any differences among these parameters measured, caused by harvest status via a one-way analysis of variance (ANOVA), or where heteroscedasticity was high, with Kruskal-Wallis tests.

\section{Measuring populations and distribution}

For the four sampling sites surveyed, we estimated the population size, based on the number of flowering individuals. For each population we noted the coordinates of all observed flowering individuals of $D$. sambucina within a square. For three of the four populations, this was a full count of the local population (those in flower). For the fourth (Lakmos), the cluster was a sample of the larger population. In describing plant distributions, it has been widely recognized that a multiscale approach is helpful [85-87]. Thus, we estimated the population density and extent on five different spatial scales. We examined the same distribution on different spatial scales by looking at the grid-occupancy on nested grids of different cell sizes. The distribution of a population can be understood by how it occupies area at different scales. If the distribution is like Poisson, the proportion of occupied cells should increase as the size of the grid cell increases. If the distribution is more towards fractal, the proportion of occupied cells is much the same regardless of spatial scale.

The inclination of the landscape means that the squares in our analysis are not the same size as the area of squares on the ground. Also, since the slope is changing in places, squares are not all the same size in different sites or at different points within the same site. Nevertheless, this error is not so great in our case because most of the slopes are about one in four (one metre rise for $4 \mathrm{~m}$ horizontal), which leads, by Pythagoras' Theorem, to an increase in size of $\operatorname{sqrt}(1+16) \sim 4.12$, that is $3.1 \%$ increase in area. In ecological systems this error is fairly small and so we do not think it causes a major problem.

\section{Estimating scale-dependent density}

In this approach, we estimated the grid occupancy on different spatial scales by using a grid with successively finer cell sizes. At a given scale, the proportion of cells occupied tells us whether the distribution is even at that scale (many occupied cells) or clustered at that scale. We move to a finer scale by dividing each occupied square into 16 sub-squares (Fig. 3). For each population studied, we 
initially defined a square of size $512 \mathrm{~m}$ with major axis aligned North-South around it. The size chosen for the bounding square of $512 \mathrm{~m}$ is so that all populations will be analyzed with the same scale and for convenience so that we have five different scales starting with a square of side $2 \mathrm{~m}$. In several cases (such as in Anilio), this area included features such as forest and roads where the plant cannot grow. Also, failure to occupy the square may be due to these but also to unseen factors such as orchid mycorrhizae. This is denoted level-0. At this level there was a single occupied square, so the average occupancy (proportion occupied) at this scale $L$ is $p_{0}=1$. The initial square was divided into 16 ("level-1") sub-squares of size $128 \mathrm{~m}$ and we counted the number of these occupied, $n_{1}$. The average occupancy (proportion occupied) at the scale $128 \mathrm{~m}$ was thus $p_{1}=n_{1} / 16$. In general, $p_{k}$ denotes a proportion of sub-squares, of size $512 / 4^{k}$ in width, that are occupied, within a mother square of size $512 / 4^{k-1}$. We selected two of the occupied level-1 squares at random. If only one was occupied $\left(n_{1}<2\right)$ we selected this occupied square. For each selected square, we proceeded to the next level, repeating steps 1 and 2 above. The occupancy was the average value obtained over all selected squares at this level. We repeated the above steps for the next levels until we reached the level where subsquares are on the order of plant size, namely a width of $0.5 \mathrm{~m}$. We noted the occupancies $p_{0}-p_{4}$ at the five different scales of square (cell) size 512, 128, 32, 8 and $2 \mathrm{~m}$. We repeated steps 1 to 5 for 1000 replicate simulations. Each time the initial square enclosing the population was

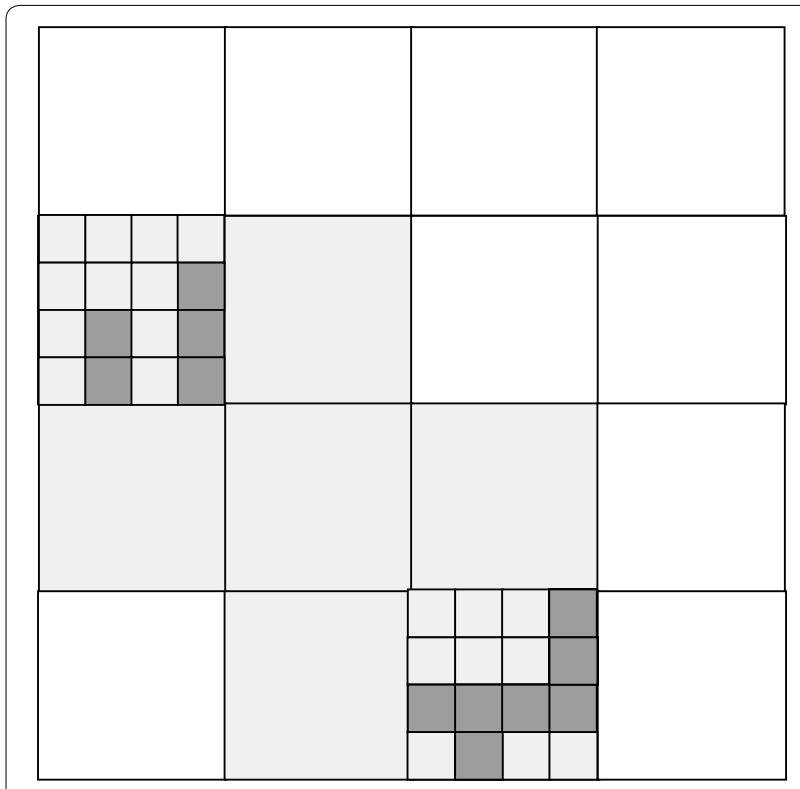

Fig. 3 Basic geometry of grid on multiple scales displaced slightly at random, constrained only to contain all the observed points. The average occupancies over the many replicates offers an estimate of the density of plants at four different scales: $\bar{p}_{1}, \bar{p}_{2}, \bar{p}_{3}$ and $\bar{p}_{4}$.

\section{Poisson model}

We fitted a Poisson model to the data. In the Poisson model of spatial distribution, each unit of area has a fixed probability of occupation. The Poisson model is a basic assumption in most non-stratified sampling schemes. If we find $N$ individuals in an area of size $A$, then we fit a Poisson model by finding $r$, the Poisson process rate, estimated by $N / A$. The probability that an area $a$ is empty is given by $p_{0}=e^{-r A}$. Thus as we move to larger scales (so area $A$ gets bigger by 16 -fold each time) the probability of a cell being empty falls rapidly. Thus, if a population is distributed randomly according to the Poisson model there is a dramatic difference in occupancy between scales, with larger areas having much higher probabilities of being occupied than smaller ones. In the Poisson model, there is a characteristic spatial scale, which is sometimes called the mean free path. This is the shortest distance an observer will have to walk between a single plant and the next one. Any randomly chosen area much smaller than this scale will probably be empty but areas much larger than this scale will be overwhelmingly occupied. In a grid-based system, for a Poisson model, as cellsize increases so does the probability of occupancy. Thus, average occupancy should increase with scale. To predict the occupancy of a given cell of area $a$ in this model, we use the fact that the probability of occupation of a single cell is $1-\exp (-r a)$, so that the expected number of occupied out of 16 cells is $16\left(1-e^{-r a}\right)$.

\section{Fractal model}

We also fitted a fractal model to the data. A fractal model of distribution has equal occupancy at all scales. If a population is distributed spatially according to a fractal model there is no systematic variation of occupancy between scales and there is no characteristic spatial scale. Fitting a distribution to a fractal model means finding best-fit fractal (usually from a specific type of fractal) to the data. An important class of fractals consists of the so-called percolation fractals [88]. These are constructed by iteratively subdividing an occupied area into equallysized sub-areas and defining each sub-area as occupied or empty according to a fixed probability generates such a distribution [89]. The probability $\left(p_{F}\right)$ and the degree of subdivision determines the fractal dimension:

$$
D=\frac{\log \left(m^{2} p_{F}\right)}{\log (m)} .
$$


Here $m$ is the number of divisions at each level (in our case 16) and $p_{F}$ is the proportion of occupied sub-squares at each level. We can assume a percolation fractal model for the distribution observed and then fit this equation using the average of the occupancies $\left\{\bar{p}_{1}, \bar{p}_{2}, \ldots, \bar{p}_{K}\right\}$ for $p_{F}$. Thus if we find the average value of Eq. (1) for $K$ different scales, each with a different $\bar{p}_{j}$, we have:

$$
\hat{D}=2+\frac{\log \langle p\rangle}{\log (m)} .
$$

Here $\left\langle p>\right.$ is the geometric average of $\left\{\bar{p}_{1}, \bar{p}_{2}, \ldots, \bar{p}_{K}\right\}$ and as $\langle p\rangle<1$, the value of $\hat{D}$ is always less than 2 . If we assume this fractal model, we can find the fractal dimension using Eq. (2). This can then be used to estimate the population [90]. For fractal distributions, the population inside a square of side $L$ increases according to the power law, $N=B L^{D}$, and then we can extrapolate population from a sample to a larger area, we can use the approximate formula:

$$
N_{2} \approx\left(\frac{L_{2}}{L_{1}}\right)^{\hat{D}} N\left(L_{1}\right) .
$$

In this approach we estimate the grid occupancy on different spatial scales by using a grid. Thus, the important parameter here, in the context of our ecological system, is the occupancy probability, $p_{F}$, which in the fractal model of this kind, is considered a constant. Thus fractal model can be fitted by finding the average occupancy over different scales.

\section{Distinguishing a poisson from a fractal pattern}

From an ecological perspective, we are interested in deciding whether these orchids are more uniformly spread throughout the site (Poisson model) or whether it corresponds to uniformity in scale (fractal model). To distinguish a fractal model from a Poisson model, note that in the Poisson model the occupancy will increase with scale whereas in the fractal model it remains constant with scale. To decide whether the observed spatial patterns were more consistent with Poisson or Fractal patterns we find the occupancy of a square by its 16 subsquares at scales $512 \mathrm{~m}, 128 \mathrm{~m}, 32 \mathrm{~m}, 8 \mathrm{~m}$ and $2 \mathrm{~m}$ by the 16 sub-squares of side $128 \mathrm{~m}, 32 \mathrm{~m}, 8 \mathrm{~m}, 2 \mathrm{~m}$ and $0.5 \mathrm{~m}$, respectively, to give $p_{F}$ at different scales. We then tested the slope of the regression of $p_{F}$ against $\log L$.

\section{Acknowledgements}

The authors wish to thank Dr. Anastasia Tzortzaki for help in fieldwork and data analysis for part of the project, and Dr. Rigas Tsiakiris for assistance during fieldwork. The authors would also like to thank the Research Committee of the University of loannina for administrative support and PALASE field station for offering accommodation during the fieldwork. We would also like to thank the editors and two anonymous referees for helpful and constructive comments.

\section{Authors' contributions}

MC, KS and JMH conceived the idea. MC and KS designed the protocols for fieldwork and interviews respectively. MC and KS participated in interviews, and MC, KS and JMH in fieldwork. MC and KK performed the analysis for orchid demography and population profiles, $\mathrm{KS}$ analyzed interview data, and JMH analyzed the population distribution patterns. All authors contributed to the writing of the manuscript. All authors read and approved the final manuscript.

\section{Funding}

This study belongs to a research program that has been co-financed by the Operational Program "Human Resources Development, Education and Lifelong Learning", the European Union (European Social Fund), and Greek National Funds (Fund Code: MIS 5006128).

\section{Availability of data and materials}

The datasets in this paper are available from the corresponding author on reasonable request.

\section{Ethics approval and consent to participate}

Not applicable.

\section{Consent for publication \\ Not applicable.}

\section{Competing interests}

The authors declare that they have no competing interests.

\section{Author details}

${ }^{1}$ Laboratory of Ecology, Department of Biological Applications \& Technology, University of loannina, 45110 loannina, Greece. ${ }^{2}$ Department of Ecology and Systematics, Faculty of Biology, National and Kapodistrian University of Athens, 15784 Athens, Greece.

Received: 14 October 2019 Accepted: 19 December 2019

Published online: 30 December 2019

\section{References}

1. Ramírez SR, Gravendeel B, Singer RB, Marshall CR, Pierce NE. Dating the origin of the Orchidaceae from a fossil orchid with its pollinator. Nature. 2007:448:1042-5.

2. Givnish TJ, Spalink D, Ames M, Lyon SP, Hunter SJ, Zuluaga A, et al. Orchid phylogenomics and multiple drivers of their extraordinary diversification. Proc R Soc B. 2015;282:20151553.

3. Poinar G, Rasmussen FN. Orchids from the past, with a new species in Baltic amber. Bot J Linn Soc. 2017;183:327-33.

4. Cribb PJ, Kell SP, Dixon KW, Barrett RL. Orchid conservation: a global perspective. In: Dixon KW, Kell SP, Barrett RL, Cribb PJ, editors. Orchid conservation. Malaysia: Natural History Publications; 2003. p. 1-24.

5. Chase MW. Classification of Orchidaceae in the Age of DNA data. Curtis's Bot Mag. 2005;22:2-7.

6. Chase MW, Cameron KM, Freudenstein JV, Pridgeon AM, Salazar G, van den Berg C, et al. An updated classification of Orchidaceae. Bot J Linn Soc. 2015;177:151-74

7. Christenhusz MJM, Byng JW. The number of known plants species in the world and its annual increase. Phytotaxa. 2016;261:201-17.

8. Bulpitt CJ. The uses and misuses of orchids in medicine. QJM. 2005;98:625-31.

9. Darwin C. On the various contrivances by which British and foreign orchids are fertilised by insects: and on the good effect of intercrossing. London UK: John Murray; 1862.

10. Bulpitt CJ, Li Y, Bulpitt PF, Wang J. The use of orchids in Chinese medicine. J R Soc Med. 2007;100:558-63.

11. Swarts ND, Dixon KW. Terrestrial orchid conservation in the age of extinction. Ann Bot. 2009;104:543-56.

12. Swarts ND, Dixon KW. Perspectives on orchid conservation in botanic gardens. Trends Plant Sci. 2009:14:590-8.

13. Pant B. Medicinal orchids and their uses: tissue culture a potential alternative for conservation. Afr J Plant Sci. 2013;7:448-67. 
14. Rubluo A, Martinez AP. University of New Mexico biocomputing workshop computation-based molecular design. Biol Conserv. 1993;63:163-9.

15. IUCN. Table $4 \mathrm{~b}$ - Numbers of species in each IUCN Red List Category in each major plant taxonomic group (Class, Family). IUCN Red List version 2019-2. 2019. https://www.iucnredlist.org/resources/summary-statistics \#Summary Tables.

16. Fay MF. Orchid conservation: how can we meet the challenges in the twenty-first century? Bot Stud. 2018;59:16.

17. Starin D. Salepi extinction, salepi survival: how a change in ingredients could help safeguard orchids. Am Orch Soc Bull. 2012;81:490-4.

18. Sezik E. Turkish Orchids and Salep. Acta Pharm Turcica. 2002;44:151-7.

19. Hossain MM. Therapeutic orchids: traditional uses and recent advancesan overview. Fitoterapia. 2011;82:102-40.

20. Speake J, LaFlaur M. The Oxford essential dictionary of foreign terms in english. Oxford: Oxford Univeristy Press; 1999.

21. Hanlidou E, Karousou R, Kleftoyanni V, Kokkini S. The herbal market of Thessaloniki (N Greece) and its relation to the ethnobotanical tradition. J Ethnopharmacol. 2004:91:281-99.

22. Hinsley A, De Boer HJ, Fay MF, Gale SW, Gardiner LM, Gunasekara RS, et al. A review of the trade in orchids and its implications for conservation. Bot J Linn Soc. 2018;186:435-55.

23. Tsioutsiou EE, Giordani P, Hanlidou E, Biagi M, De Feo V, Cornara L. Ethnobotanical study of medicinal plants used in central Macedonia, Greece. Evid Based Complement Alternat Med. 2019;2019:4513792.

24. Dogan M, Kayacier A. Rheological properties of reconstituted hot salep beverage. Int J Food Prop. 2004;7:683-91.

25. Ghorbani A, Gravendeel B, Naghibi F, de Boer H. Wild orchid tuber collection in Iran: a wake-up call for conservation. Biodivers Conserv. 2014:23:2749-60.

26. Kreziou A, de Boer H, Gravendeel B. Harvesting of salep orchids in north-western Greece continues to threaten natural populations. Oryx. 2015;50:393-6.

27. Hinsley A, Verissimo D, Roberts DL. Heterogeneity in consumer preferences for orchids in international trade and the potential for the use of market research methods to study demand for wildlife. Biol Conserv. 2015;190:80-6.

28. Tsiftsis S, Tsiripidis I. Orchids of Northern Pindos National Park. Aspraggeloi, Zagori Municipality. Ioannina: Management Agency of Vikos-Aoos and Pindos National Forests; 2015.

29. Tsiftsis S, Štípková Z, Kindlmann P. Role of way of life, latitude, elevation and climate on the richness and distribution of orchid species. Biodivers Conserv. 2019:28:75-96.

30. Zioga E. Utility value of flora of Zagori area: A natural and cultural heritage. MSc Thesis. Thessaloniki: Aristotle University of Thessaloniki; 2016

31. Landerer X. Naturgeschichte und Pharmakognosie. Beiträge zur Pharmakognosie. Ueber Salep und die Salepisiden. Arch Pharm (Weinheim) 1850;112:177-80.

32. Lazarides K. Botanical and Folk Elements of the Flora of My Village Koukouli. loannina: Zagori and of the Vikos Gorge; 1986.

33. Malamas M, Marselos M. The tradition of medicinal plants in Zagori, Epirus (northwestern Greece). J Ethnopharmacol. 1992:37:197-203.

34. Kasparek M, Grimm U. European trade in Turkish Salep with special reference to Germany. Econ Bot. 1999;53:396-406.

35. Jenkins M, Timoshyna A, Cornthwaite M. Wild at Home: Exploring the global harvest, trade and use of wild plant ingredients. Cambridge; 2018.

36. Wiersum KF, Wong JLG, Vacik H. Perspectives on non-wood forest product development in Europe. Int For Rev. 2018;20:250-62.

37. De Boer HJ, Ghorbani A, Manzanilla V, Raclariu AC, Kreziou A, Ounjai S, et al. DNA metabarcoding of orchid-derived products reveals widespread illegal orchid trade. Proc Biol Sci. 2017;284:20171182

38. FOREST EUROPE. State of Europe's Forests 2015. Madrid; 2015

39. Hedrén $M$, Nordström S, Persson Hovmalm HA, Pedersen $H Æ$, Hansson S. Patterns of polyploid evolution in Greek marsh orchids (Dactylorhiza; Orchidaceae) as revealed by allozymes, AFLPs, and plastid DNA data. Am J Bot. 2007;94:1205-18.

40. Tsiftsis S, Tsiripidis I, Karagiannakidou V. Identifying areas of high importance for orchid conservation in east Macedonia (NE Greece). Biodivers Conserv. 2009;18:1765-80.

41. Tsiftsis S, Tsiripidis I. Threat categories of the Greek orchids (Orchidaceae). Bot Chron. 2016;21:43-74.
42. Tsiftsis S, Tsiripidis I, Karagiannakidou V, Alifragis D. Niche analysis and conservation of the orchids of east Macedonia (NE Greece). Acta Oecol. 2008:33:27-35

43. IUCN Standards and Petitions Committee. Guidelines for Using the IUCN Red List Categories and Criteria. IUCN Red List. 2019. http://www.iucnr edlist.org/documents/RedListGuidelines.pdf.

44. QGIS Development Team. QGIS Geographic Information System. Open Source Geospatial Foundation Project. 2019. http://qgis.osgeo.org.

45. Rankou H. Dactylorhiza sambucina. IUCN Red List Threat Species 2011. 2011;e.T175983A7162528.

46. Alexander BW, Kirby D, Biondini M, Dekeyser E. Cattle grazing reduces survival and reproduction of the western prairie fringed orchid. Prairie Nat. 2010;42:46-9.

47. Sonne MN, Hauser TP. Population fluctuations, losses to grazing, and reproductive success of Dactylorhiza sambucina on Bornholm, Denmark. Ann Bot Fenn. 2014:51:375-86.

48. Bleho Bl, Koper N, Borkowsky CL, Hamel CD. Effects of Weather and Land Management on the Western Prairie Fringed-orchid (Platanthera praeclara) at the Northern Limit of its Range in Manitoba, Canada. Am Midl Nat. 2015:174:191-203.

49. Gerasimidis A, Panajiotidis S, Fotiadis G, Korakis G. Review of the Quaternary vegetation history of Epirus (NW Greece). Phytol Balcan. 2009; 15:29-37.

50. Campbell JK. Honour, Family and Patronage. A Study of Institutions and Moral Values in a Greek Mountain Community. Oxford: Clarendon Press; 1964.

51. Mincheva I, Kozuharova E. Is the traditional use of "salep" in the Bulgarian Rhodopes hazardous for the wild populations of terrestrial orchids? Flora Mediterr. 2018;28:399-418.

52. Jersáková J, Traxmandlová I, Ipser Z, Kropf M, Pellegrino G, Schatz B, et al. Biological flora of Central Europe: Dactylorhiza sambucina (L.) Soó. Perspect Plant Ecol. 2015;17:318-29.

53. Fischer M, Wipf S. Effect of low-intensity grazing on the species-rich vegetation of traditionally mown subalpine meadows. Biol Conserv. 2002;104:1-11.

54. Köhler M, Hiller G, Tischew S. Year-round horse grazing supports typical vascular plant species, orchids and rare bird communities in a dry calcareous grassland. Agric Ecosyst Environ. 2016;234:48-57.

55. Blondel J. The, "design" of Mediterranean landscapes: a millennial story of humans and ecological systems during the historic period. Hum Ecol. 2006;34:713-29.

56. Papanastasis VP. Livestock grazing in Mediterranean ecosystems: an historical and policy perspective. In: Papanastasis VP, Peter D, editors. Ecological basis for livestock grazing in mediterranean ecosystems. Luxemburg: European Commission; 1998. p. 5-9.

57. Rackham O, Moody J. The making of the Cretan Landscape. Manchester: Manchester University Press; 1996.

58. Zomeni M, Tzanopoulos J, Pantis JD. Historical analysis of landscape change using remote sensing techniques: an explanatory tool for agricultural transformation in Greek rural areas. Landsc Urban Plan. 2008;86:38-46.

59. Stara K, Sidiropoulos L, Tsiakiris R. Bound Eagles, Evil Vultures and Cuckoo Horses. Preserving the bio-cultural diversity of carrion eating birds. Hum Ecol. 2016;44:751-64.

60. Hinsley A, Nuno A, Ridout M, John FAVS, Roberts DL. Estimating the extent of CITES noncompliance among traders and end-consumers; lessons from the Global Orchid Trade. Conserv Lett. 2017;10:602-9.

61. Peintner U, Schwarz S, Mešić A, Moreau PA, Moreno G, Saviuc P. Mycophilic or Mycophobic? Legislation and guidelines on wild mushroom commerce reveal different consumption behaviour in European countries. PLOS ONE. 2013;8:e63926.

62. Pauly D. Anecdotes and the shifting baseline syndrome of fisheries. Trends Ecol Evol. 1995;10:430.

63. Ghimire SK, McKey D, Aumeeruddy-Thomas Y. Conservation of Himalayan medicinal plants: harvesting patterns and ecology of two threatened species, Nardostachys grandiflora DC. and Neopicrorhiza scrophulariiflora (Pennell) Hong. Biol Conserv. 2005;124:463-75.

64. Halley JM, Van Houtan KS, Mantua N. How survival curves affect populations'vulnerability to climate change. PLoS ONE. 2018;13:e0203124. 
65. Egli S, Peter M, Buser C, Stahel W, Ayer F. Mushroom picking does not impair future harvests - results of a long-term study in Switzerland. Biol Conserv. 2006;129:271-6.

66. van Houtan KS, Halley JM. Long-term climate forcing in loggerhead sea turtle nesting. PLOS ONE. 2011;6:e19043.

67. Staude IR, Navarro LM, Pereira HM. Range size predicts the risk of local extinction from habitat loss. Glob Ecol Biogeogr. 2020;29:16-25.

68. Newbold T, Hudson LN, Contu S, Hill SLL, Beck J, Liu Y, et al. Widespread winners and narrow-ranged losers: land use homogenizes biodiversity in local assemblages worldwide. PLoS Biol. 2018;16:e2006841.

69. Rasmussen HN, Dixon KW, Jersáková J, Těšitelová T. Germination and seedling establishment in orchids: a complex of requirements. Ann Bot. 2015;116:391-402.

70. Reiter N, Whitfield J, Pollard G, Bedggood W, Argall M, Dixon K, et al. Orchid re-introductions: an evaluation of success and ecological considerations using key comparative studies from Australia. Plant Ecol. 2016;217:81-95.

71. Reiter N, Lawrie AC, Linde CC. Matching symbiotic associations of an endangered orchid to habitat to improve conservation outcomes. Ann Bot. 2018;122:947-59.

72. Gale SW, Fischer GA, Cribb PJ, Fay MF. Orchid conservation: bridging the gap between science and practice. Bot J Linn Soc. 2018;186:425-34

73. Gault A, Meinard Y, Courchamp F. Consumers' taste for rarity drives sturgeons to extinction. Conserv Lett. 2008;1:199-207.

74. Lyons JA, Natusch DJD. Effects of consumer preferences for rarity on the harvest of wild populations within a species. Ecol Econ. 2013;93:278-83.

75. Dimopoulos P, Raus T, Bergmeier E, Constantinidis T, latrou G, Kokkini S, et al. Vascular Plants of Greece: an annotated checklist. Berlin: Botanischer Garten und Botanischers Museum Berlin-Dahlem \& Hellenic Botanical Society; 2013

76. Dimopoulos P, Raus T, Bergmeier E, Constantinidis T, latrou G, Kokkini S, et al. Vascular plants of Greece: an annotated checklist. Supplement. Willdenowia. 2016:46:301-47.

77. Tsiakiris R, Stara K. The "salep" traders of Pindos mountains in Greece. Paper presented at International Conference on Wild Forest Products in Europe; Barcelona; 2016.
78. Bornovas I., Rondogianni-Tsiambaou T. Geological map of Greece. Scale 1:500 000, Second Edition. Institute of Geology and Mineral Exploration, Division of General Geology and Economic Geology, Athens, Greece; 1983.

79. Delforge P. Orchids of Europe, North Africa and the Middle East. 3rd ed. London: A\&C Black; 2006.

80. Tsiftsis S, Antonopoulos Z. Atlas of the Greek Orchids, vol. 1. Mediterraneo Editions: Rethymnon, Greece; 2017.

81. Martin GJ. Ethnobotany: a methods manual. Boston: Springer; 1995.

82. Nichols P. Social survey methods: a field guide for development workers (Oxfam Development Guidelines). Oxfam: Oxfam Professional; 1991.

83. Molnár VA, Nagy T, Löki V, Süveges K, Takács A, Bódis J, et al. Turkish graveyards as refuges for orchids against tuber harvest. Ecol Evol. 2017;7:11257-64.

84. Sonkoly J, Vojtkó AE, Tökölyi J, Török P, Sramkó G, Illyés Z, et al. Higher seed number compensates for lower fruit set in deceptive orchids. J Ecol. 2016;104:343-51.

85. Kunin WE. Extrapolating species abundance across spatial scales. Science. 1998;281:1513-5

86. Tsiftsis S, Tsiripidis I, Trigas P. Identifying important areas for orchid conservation in Crete. Eur J Environ Sci. 2009;1:28-37.

87. Tzortzaki AE, Vokou D, Halley JM. Campanula lingulata populations on Mt. Olympus, Greece: where's the "abundant centre"? J Biol Res. 2017;24:1.

88. Falconer K. Fractal geometry. Chichester: Wiley; 1990.

89. Halley JM, Hartley S, Kallimanis AS, Kunin WE, Lennon JJ, Sgardelis SP. Uses and abuses of fractal methodology in ecology. Ecol Lett. 2004;7:254-71.

90. Zakkak S, Panagiotopoulou M, Halley JM. Estimating the abundance of shearwaters and gulls in the North Aegean sea. Mar Ornithol. 2013:41:141-8.

\section{Publisher's Note}

Springer Nature remains neutral with regard to jurisdictional claims in published maps and institutional affiliations.
Ready to submit your research? Choose BMC and benefit from:

- fast, convenient online submission

- thorough peer review by experienced researchers in your field

- rapid publication on acceptance

- support for research data, including large and complex data types

- gold Open Access which fosters wider collaboration and increased citations

- maximum visibility for your research: over $100 \mathrm{M}$ website views per year

At BMC, research is always in progress.

Learn more biomedcentral.com/submissions 